\title{
Dark Response of Seedlings Evaluated by Chlorophyll Concentration in Maize Natural Population
}

\author{
Aye Nyein Chan ${ }^{1,2 *}$, Shutu Xu ${ }^{1,2^{*}}$, Dongwei Guo ${ }^{1,2}$, Yaqin Shi1, ${ }^{1,2}$ Yanan $\mathrm{Li}^{1,2}$, Yajun Li1, \\ Jiquan Xue ${ }^{1,2 \#}$ \\ ${ }^{1}$ College of Agronomy, Northwest A\&F University, Yangling, China \\ ${ }^{2}$ Key Laboratory of Biology and Genetic Improvement of Maize in Arid Area of Northwest Region, Ministry of \\ Agriculture, Yangling, China \\ Email: chanchananc@gmail.com, shutuxu@nwafu.edu.cn, "xjq2934@163.com
}

Received 17 July 2015; accepted 27 August 2015; published 31 August 2015

Copyright (C) 2015 by authors and Scientific Research Publishing Inc.

This work is licensed under the Creative Commons Attribution International License (CC BY). http://creativecommons.org/licenses/by/4.0/

(c) (i) Open Access

\begin{abstract}
Chlorophyll, one of the major chloroplast components for photosynthesis, has a positive relationship with the photosynthetic rate. The chlorophyll content is an important assessment parameter in agronomy and plant biology research. This study was conducted to evaluate the natural variation in the chlorophyll content and to determine the differential response of the chlorophyll concentration to dark treatment in a natural population containing 139 maize inbreds. A five-fold higher chlorophyll concentration was measured in the light compared with the dark. Meanwhile, the wide variation in the chlorophyll concentration showed the differential response of the natural maize population to dark. Finally, we identified some inbreds that were highly sensitive to the dark with more than $\mathbf{7 0 \%}$ difference between the light and dark treatment, such as Dan598, Zheng29, Zheng35, DH29, and R08, as well as some inbreds that had lower sensitivity to the dark, with less than $35 \%$ difference in the chlorophyll content between the light and dark treatment, such as Chuan48-2, 4F1, 303WX, 9642, and LY042.
\end{abstract}

\section{Keywords}

Maize, Inbred Lines, Seedlings, Chlorophyll, Dark Treatment

\section{Introduction}

As the most important pigment in the world, chlorophyll (Chl) plays a central role in photosynthesis and is re*These authors contributed equally to this work.

"Corresponding author.

How to cite this paper: Aye, N.C., Xu, S.T., Guo, D.W., Shi, Y.Q., Li, Y.N., Li, Y.J. and Xue, J.Q. (2015) Dark Response of Seedlings Evaluated by Chlorophyll Concentration in Maize Natural Population. American Journal of Plant Sciences, 6, $2209-2219$. http://dx.doi.org/10.4236/ajps.2015.613223 
sponsible for absorbing sunlight and converting it into chemical energy [1]. Maintaining a higher Chl content for a longer period in the reproductive stage is essential for increasing crop production [2] [3]. However, excess Chl in its free state produces reactive oxygen species and results in cell death [4]; therefore, plant cells must degrade these species through self-metabolism. Green plants contain two major Chl components, chlorophyll a (Chla) and chlorophyll b (Chlb), both with the same absorption spectra [5] [6]. Chla and Chlb function as photoreceptors in photosynthesis. Chla is a unique pigment that exists in all oxygenic photosynthetic organisms [7]. Chlb functions in the light-harvesting Chla/b protein complexes (LHCs) that harvest and transfer light energy to both photosystems [8].

The Chl content is an important experimental parameter in agronomy and plant biology research [9]. The Chl content is used as an effective index to assess photosynthetic efficiency in breeding programs [10]. This parameter is fundamental to understanding the response of a plant to the adverse environment in which it resides. Because it is a quantitative trait, it is difficult to select for Chl content in breeding programs [11]. The amount of Chl varies depending on many edaphic and climatic factors, such as salt stress [12]-[14], light [15]-[19], water stress [20]-[25], air pollution [26], fertilization [27], the vegetation period [28], plant species and leaf position [29]. Therefore, the tolerance of plants for stresses such as cold and drought [30]-[33] or low temperature [34] [35] can be determined by the Chl concentration.

Maize (Zea mays L.) is the world's most widely grown crop. It is also an important source of biofuel, animal feed and raw material in industry [36]. In addition, maize is an important model organism for cytogenetic, genetic, genomic, and functional genomic studies based on complete whole genome sequencing [37]. Increasing the grain yield and biomass per acre is one of the most important goals of maize production [38]. Nowadays, adverse weather and environmental diversity threaten maize yield, which has resulted in a research hotpot on the maize response to adverse environmental conditions. In this present study, a natural population with 139 inbred maize lines was used to investigate the variation in the Chl content before and after dark treatment and to evaluate the response of different inbred lines to dark treatment.

\section{Materials and Methods}

\subsection{Experimental Conditions and Treatments}

The inbred maize lines were provided by the National Maize Improvement Centre of China [39]. Two seed replicates were germinated in petri dishes for 4 days and transplanted to enriched soil (light nutritional soil: vermiculite $=1: 1$ ) under the following growth conditions: light/dark: 10/14 hours; temperature: $25^{\circ} \mathrm{C}$; white light: 400 $\mu \mathrm{mol} \cdot \mathrm{m}^{-2} \cdot \mathrm{s}^{-1}$. When the second leaf had emerged completely, one replicate was placed under light and the other was placed in the dark for four days. All the phenotypic data were collected after four days of dark treatment.

\subsection{Phenotypic Determination and Analysis}

When two leaves had fully unfolding, two types of methods were used for Chl determination before and after 4 days of dark treatment. The first method was the use of the SPAD-502 chlorophyll meter (Minolta Camera Co., Osaka, Japan) and the second was the chemical method in which Chl from the green part of three plants was extracted using 80\% acetone and measured using spectrophotometer at wavelengths of $645 \mathrm{~nm}$ and $663 \mathrm{~nm}$ [40]. All data were analyzed by using SPSS v.19 software and the Microsoft Excel program, including basic statistics description, mono factor analysis of variance and Pearsoncorrelation. The relative contents of chlorophyll a, b and total chlorophyll $(\mathrm{Tchl}=\mathrm{Chla}+\mathrm{Chlb})$ and Chla/b $(\mathrm{Chla} / \mathrm{Chlb})$ were calculated using the following equations [40].

$$
\begin{aligned}
& \operatorname{Chla}(\mathrm{mg} / \mathrm{g})= \mathrm{N} \frac{\left(\left(12.21 \times \mathrm{A}_{663}\right)-\left(2.81 \times \mathrm{A}_{645}\right)\right) \times \mathrm{V}}{(1000 \times \mathrm{W})} \\
& \operatorname{Chlb}(\mathrm{mg} / \mathrm{g})= \mathrm{N} \frac{\left(\left(20.13 \times \mathrm{A}_{645}\right)-\left(5.03 \times \mathrm{A}_{663}\right)\right) \times \mathrm{V}}{(1000 \times \mathrm{W})} \\
& \operatorname{TChl}(\mathrm{mg} / \mathrm{g})=\text { Chla }+ \text { Chlb } \\
& \text { Chl } / \mathrm{b}=\text { Chla } / \text { Chlb }
\end{aligned}
$$


where $\mathrm{A}_{645}=$ absorbance at $645 \mathrm{~nm} ; \mathrm{A}_{663}=$ absorbance at $663 \mathrm{~nm}$; $\mathrm{V}=$ solvent volume, $\mathrm{W}=$ fresh weight of the extracted tissue, $\mathrm{N}=$ dilution factor.

\section{Results}

\subsection{Phenotypic Analysis}

In general, there was wide variation in the SPAD value and the Chl concentration measured in the light and dark. The average SPAD values were 38.02 and 29.83 under light and dark conditions, respectively, and the variation was double that measured in the natural population. The largest values were 48.35 from ZaC546 and 42.12 from Shen137, and the smallest SPAD values were 26.33 from NMJT and 18.32 from HSBN under light and dark conditions, respectively. This suggested that a smaller variation of 22.03 was observed in the light compared with a greater variation of 23.80 in the dark (Table 1).

For the Chla, Chlb, and Tchl concentrations, there was two-fold difference between the light and dark for the average values; however, a small difference was observed in Chla/b under light and dark conditions. The average Chla concentration was $0.57 \mathrm{mg} / \mathrm{g}$ (range $=1.03 \mathrm{mg} / \mathrm{g}$ ) in the light, compared with $0.22 \mathrm{mg} / \mathrm{g}$ (range $=0.54$ $\mathrm{mg} / \mathrm{g}$ ) in the dark. The variation of Chlain the population was more than ten-fold, and ranged from $0.18-1.21$ $\mathrm{mg} / \mathrm{g}$ and $0.04-0.58 \mathrm{mg} / \mathrm{g}$ under light and dark conditions, respectively. The highest concentration was measured in Mo17 and the lowest in K14 in the light, compared with the highest concentration in TY-2 and the lowest in Zheng-35 in the dark. The Chlb concentrations ranged from $0.26 \mathrm{mg} / \mathrm{g}$ (238) to $0.96 \mathrm{mg} / \mathrm{g}$ (Qi319) in the light, i.e., almost a four-fold variation, compared with the range from $0.06 \mathrm{mg} / \mathrm{g}$ (Dan598) to $0.58 \mathrm{mg} / \mathrm{g}$ (TY-2) in the dark, i.e., almost a ten-fold variation. The average Chlb concentrations determined in the light and dark were $0.52 \mathrm{mg} / \mathrm{g}$ and $0.26 \mathrm{mg} / \mathrm{g}$, respectively. The Tchl concentration in the light ranged from $0.55-2.05 \mathrm{mg} / \mathrm{g}$, with a high variation of $1.51 \mathrm{mg} / \mathrm{g}$ and an average value of $1.09 \mathrm{mg} / \mathrm{g}$, compared with the range of $0.12-1.16$ $\mathrm{mg} / \mathrm{g}$, a variation of $1.05 \mathrm{mg} / \mathrm{g}$ and an average of $0.49 \mathrm{mg} / \mathrm{g}$ measured under dark conditions. The Chla/b range was $0.44-1.49$ and the average was 1.07 under light conditions, compared with the range of $0.09-1.21$ and the average of 0.84 under dark conditions. When we measured the Chla and Chlb percent in Tchl under light and dark conditions, only a small difference was found between the average values. A two-fold variation in the Chla percent in Tchl (range of 30.95 - 59.92) was observed in the light, and a seven-fold variation was measured in the dark (range of 8.26 - 54.79). With respect to the Chlb percent in Tchl, there was a two-fold variation under the light and dark conditions, where ranges of 40.08 - 69.05 and 45.21 - 91.74, respectively, were measured (Table 1). Under light conditions, a higher Chla percent was observed compared with a lower value under dark conditions. This indicates that the seedlings required the condition of a distribution in the Chla and Chlb concentrations to adapt to changes in the environment.

\subsection{Correlation Coefficients between the SPAD Readings and the Chl Concentration}

To explore the relationship between the SPAD readings and the Chl concentration, Pearson correlation coefficients were calculated for the different treatments as shown in Table 2. For the SPAD readings, there was a highly significant relationship, with a value of 0.561 , between the light and dark. However, no significant correlation was detected between the SPAD readings and the Chl concentration for the light or dark treatment. Furthermore, there was no significant correlation between the light and dark treatment for a particular Chl component, including Chla/b. Chla under light conditions was highly significantly positively correlated with Chlb (0.845), Tchl (0.973), and Chla/b (0.608), similar to the dark conditions. In addition, a highly significant positive relationship was also found between Chlb and Tchl, i.e., 0.944 and 0.949 under light and dark conditions, respectively. Chla/b had a highly significant positive correlation with Chla (0.608) but not with Chlb or Tchl under light conditions, and similar associations were observed in the dark. There was no significant difference in the chlorophyll components between the different treatments (Table 2).

\subsection{Difference in Chl Concentration under Light and Dark Conditions}

The relative difference in the Chl content between the light and dark treatments was also analyzed for this population, as shown in Table S1. It was found that the Top 10 least difference for Tchl was less than 35\%, and the inbreds were Chuan48-2, 4F1, 303WX, 9642, and LY042. However, the difference between the Chla and Chlb 
contents was less than $40 \%$. Therefore, we considered that these inbreds could be insensitive to dark treatment. On the other hand, it was determined that the inbreds Dan598, Zheng29, Zheng35, DH29, and R08 obtained the Top highest difference percent of more than $70 \%$ for Tchl and Chla, and a difference percent of more than $60 \%$ for Chlb. Compared with Chlb, Tchl and Chla showed a more rapid degradation under dark treatment, which suggested that these inbreds might be highly sensitive to dark treatment.

In particular, there was a miniscule increment in Chla in inbreds 4F1 and 9642, with a small decrease in Tchl and a higher decrease in Chlb. Meanwhile, there was a small increment in Chla in inbred 303WX, which exhibited a 15\% decrease in Chla and a 7\% decrease in Tchl. This result verified that the mode of transition between Chla and Chlb during the dark treatment differed between individual inbred lines (Table S1).

\section{Discussion}

A significant relationship between SPAD readings and the Chl concentration was determined by using chemical extraction in a previous report [41]; however, this relationship was not significant in the current study. It was possible that a different leaf part was used for the chemical extraction. In this study, which was in contrast to previous reports, only the middle section of the first leaf was measured by using the SPAD-502 meter, and all the green parts of the seedling were used for Chl determination. In other studies, however, the same part of the ear leaf was used to evaluate the Chl content.

According to differences in their Chl contents between light and dark, inbred lines were identified as sensitive or insensitive to dark. Inbreds such as Dan598, Zheng29, Zheng35, DH29, and R08 will be likely senescence rapidly under dark conditions, and Chuan48-2, 4F1, 303WX, 9642, and LY042 exhibit a stay-green phenotype with slow senescence in the dark. In addition, there were several inbred lines that exhibited a miniscule increment in one type of Chl but a decrease in another type of Chl and in Tchl. It can be concluded that the mechanism of transition between Chla and Chlb is different in different inbred lines under dark conditions.

Contrary to our expectations, Qi319 was not identified as a stay-green inbred under dark induced-senescence at the seedling stage, although it was classified as a stay-green type at the mature stage according to reference [41]. We infer that the mechanisms in the maize leaf differ under natural and induced senescence. This is consistent with the conclusion from the differential expression analysis using transcription analysis [42].

\section{Conclusion}

The amount of Chl in leaves varies and is affected by many factors. In this study, it was observed that the Chl concentration was five-fold higher in the light than in the dark, and inbreds that were sensitive or insensitive to dark treatment were identified according to their different response to dark. During the dark treatment, the transition between Chla and Chlb was different in the different inbreds. Moreover, a difference was observed between natural and induced leaf senescence in maize. Determination of Chl content can be used in many field studies, and its related research should be increased and performed for efficient use of Chl content.

\section{Acknowledgements}

We greatly acknowledge Dr. Yan J.B. from Huazhong Agriculture University and Dr. Yang X.H. from China Agriculture University for supplying the inbred maize lines. We also thank for the foundation of Chinese Universities Scientific Fund of Northwest A\&F University (Z109021515) and the PhD research startup foundation of Northwest A\&F University (Z109021408). We thank LetPub (www.letpub.com) for its linguistic assistance during the preparation of this manuscript.

\section{Author Contributions}

Conceived and designed the experiments: Xue, J. Q. and Xu, S. T.; Performed the experiments: Aye, N. C., Shi, Y. Q. and Li, Y. N.; Analyzed the data: Aye, N. C. and Xu, S. T.; Contributed to modify the manuscripts: Li, Y. J., Guo, D. W. and Xue, J. Q.; Wrote the paper: Xu, S. T. and Aye, N. C.,

\section{Competing Interests}

The authors have declared that no competing interests exist. 


\section{References}

[1] Tanaka, A. and Tsuji, H. (1985) Appearance of Chlorophyll-Protein Complexes in Greening Barley Seedlings. Plant \& Cell Physiology, 26, 893-902.

[2] Guo, P.G. and Li, M.Q. (1996) Studies on Photosynthetic Characteristics in Rice Hybrid Progenies and Their Parents I. Chlorophyll Content, Chlorophyll-Protein Complex and Chlorophyll Fluorescence Kinetics. Journal of Tropical and Subtropical Botany, 4, 60-65.

[3] Guo, P.G., Baum, M., Varshney, R.K., Graner, A., Grando, S. and Ceccarelli, S. (2008) QTLs for Chlorophyll and Chlorophyll Fluorescence Parameters in Barley under Post-Flowering Drought. Euphytica, 163, 203-214. http://dx.doi.org/10.1007/s10681-007-9629-6

[4] Op den Camp, R.G., Przybyla, D., Ochsenbein, C., Laloi, C., Kim, C.C., Danon, A., Wagner, D., Hideg, E., Gobel, C., Feussner, I., Nater, M. and Apel, K. (2003) Rapid Induction of Distinct Stress Responses after the Release of Singlet Oxygen in Arabidopsis. Plant Cell, 15, 2320-2332. http://dx.doi.org/10.1105/tpc.014662

[5] Ito, H. and Tanaka, A. (1996) Determination of the Activity of Chlorophyll b to Chlorophyll a Conversion during Greening of Etiolated Cucumber Cotyledons by Using Pyrochlorophyllide b. Plant Physiology and Biochemistry, 34, 35-40.

[6] Rüdiger, W. (2002) Biosynthesis of Chlorophyll b and the Chlorophyll Cycle. Photosynthesis Research, 74, $187-193$. http://dx.doi.org/10.1023/A:1020959610952

[7] Barber, J., Morris, E . and Büchel, C. (2000) Revealing the Structure of the Photosystem II Chlorophyll Binding Proteins, CP43 and CP47. Biochimica et Biophysica Acta (BBA)—Bioenergetics, 1459, 239-247. http://dx.doi.org/10.1016/S0005-2728(00)00158-4

[8] Grossman, A.R., Bhaya, D., Apt, K.E. and Kehoe, D.M. (1995) Light Harvesting Complexes in Oxygenic Photosynthesis: Diversity, Control, and Evolution. Annual Review of Genetics, 29, 231-288. http://dx.doi.org/10.1146/annurev.ge.29.120195.001311

[9] Lamb, J.J., Eaton-Rye, J.J. and Hohmann-Marriott, M.F. (2012) An LED-Based Fluorometer for Chlorophyll Quantification in the Laboratory and in the Field. Photosynthesis Research, 114, 59-68. http://dx.doi.org/10.1007/s11120-012-9777-y

[10] Kannanngarak, C.G. (1991) The Photosynthetic Apparatus. Academic Press Inc., San Diego.

[11] Wu, P. and Luo, A.C. (1996) Investigation on Genetic Background of Leaf Chlorophyll Content Variation in Rice under Nitrogen Stressed Condition via Molecular Markers. Acta Genetica Sinica, 23, 431-438.

[12] Yildirım, E., Turan, M. and Guvenç, I. (2008) Effect of Foliar Salicylic Acid Applications on Growth, Chlorophyll, and Mineral Content of Cucumber Grown under Salt Stress. Journal of Plant Nutrition, 31, 593-612. http://dx.doi.org/10.1080/01904160801895118

[13] Sevengor, S., Yasar, F., Kusvuran, S. and Ellialtioglu, S. (2011) The Effect of Salt Stress on Growth, Chlorophyll Content, Lipid Peroxidation and Antioxidative Enzymes of Pumpkin Seedling. African Journal of Agricultural Research, 6, 4920-4924.

[14] Avcioglu, R., Demiroglu, G., Khalvati, M.A. and Geren, H. (2003) Effects of Osmotic Pressure on Early Growing Stages of Some Crop Plants II. Proline, Chlorophile Accumulation and Membrane Integrity. Ziraat Fakültesi Dergisi, 40, 9-16.

[15] Johnston, M. and Onwueme, I.C. (1998) Effect of Shade on Photosynthetic Pigments in the Tropical Root Crops: Yam, Taro, Tannia, Cassava and Sweet Potato. Experimental Agriculture, 34, 301-312. http://dx.doi.org/10.1017/s0014479798343033

[16] Dai, Y.J., Shen, Z.G., Liu, Y., Wang, L.L., Hannaway, D. and Lu, H.F. (2009) Effects of Shade Treatments on the Photosynthetic Capacity, Chlorophyll Fluorescence, and Chlorophyll Content of Tetrastigma hemsleyanum Diels et Gilg. Environmental and Experimental Botany, 65, 177-182. http://dx.doi.org/10.1016/j.envexpbot.2008.12.008

[17] Khan, S.R., Rose, R., Haase, D.L. and Sabin, T.E. (2000) Effects of Shade on Morphology, Chlorophyll Concentration and Chlorophyll Fluorescence of Four Pacific Northwest Conifer Species. New Forests, 19, 171-186. http://dx.doi.org/10.1023/A:1006645632023

[18] Demircioglu, N. and Y1lmaz, H. (2005) Light Pollution: Problems and Solution Proposals. Ataturk Üniversitesi Ziraat Fakültesi Dergisi, 36, 117-123.

[19] Guneş, A. and Inal, A. (1995) The Effect of Foliar Applied Glucose on the Yield and Chlorophyll Content of Wheat (Triticum aestium L.) Grown at Different Photoperiods. Pamukkale Üniversitesi Mühendislik Fakültesi, Mühendislik Bilimleri Dergisi, 1, 69-72.

[20] Mena-Violante, H.G., Ocampo-J1menez, O., Dendooven, L., Martinez-Soto, G., Gonzolaz-Castenada, J., Fredt-Davies, J.R., Olalde-Portugal, V. and Arbuscular, V. (2006) Arbuscular Mycorrhizal Fungi Enhance Fruit Growth and Quality 
of Chile Ancho (Capsicum annuum L. cv San Luis) Plants Exposed to Drought. Mycorrhiza, 16, 261-267. http://dx.doi.org/10.1007/s00572-006-0043-z

[21] Vij, S. and Tyagi, A.K. (2007) Emerging Trends in the Functional Genomics of the Abiotic Stress Response in Crop Plants. Plant Biotechnology Journal, 5, 361-380. http://dx.doi.org/10.1111/j.1467-7652.2007.00239.x

[22] Aguero, M.V., Barg, M.V., Yommi, A., Camelo, A. and Roura, S.I. (2008) Postharvest Changes in Water Status and Chlorophyll Content of Lettuce (Lactuca sativa L.) and Their Relationship with Overall Visual Quality. Journal of Food Science, 73, 47-55. http://dx.doi.org/10.1111/j.1750-3841.2007.00604.x

[23] Şevik, H., Guney, D., Karakas, H. and Aktar, G. (2012) Change to Amount of Chlorophyll on Leaves Depend on Insolation in Some Landscape Plants. International Journal of Environmental Science, 3, 1057-1064.

[24] Demirel, K., Genc, L., Camoglu, G. and Asık, S. (2010) Assessment of Water Stress Using Chlorophyll Readings and Leaf Water Content for Watermelon. Journal of Tekirdag Agricultural Faculty, 7, 155-162.

[25] Kalefetoglu, T. and Ekmekçi, Y. (2005) The Effects of Drought on Plants and Tolerance Mechanisms (Review). Gazi University Journal of Science, 18, 723-740.

[26] Elkoca, E. (2003) Air Pollution and Its Effects on Plants. Ataturk Üniversitesi Ziraat Fakültesi Dergisi, 34, 367-374.

[27] Tunal, M.M., Çarpıcı, E.B. and Çelik, N. (2012) Effects of Different Nitrogen Rates on Chlorophyll Content, Leaf Area Index and Grain Yield of Some Maize Cultivars. Tarım Bilimleri Araştırma Dergisi, 5, 131-133.

[28] Zavoruev, V.V. and Zavorueva, E.N. (2002) Changes in the Ratio between the Peaks of Red Chlorophyll Fluorescence in Leaves of Populus balsamifera during Vegetation. Doklady Biochemistry and Biophysics, 387, 1-6.

[29] Gond, V., De Pury, D.G.G., Veroustraete, F. and Ceulemans, R. (2012) Seasonal Variations in Leaf Area Index, Leaf Chlorophyll, and Water Content; Scaling-Up to Estimate fAPAR and Carbon Balance in a Multilayer, Multispecies Temperate Forest. Tree Physiology, 19, 673-679. http://dx.doi.org/10.1093/treephys/19.10.673

[30] Perks, M.P., Osborne, B.A. and Mitchell, D.T. (2004) Rapid Predictions of Cold Tolerance in Douglas-Fir Seedlings Using Chlorophyll Fluorescence after Freezing. New Forests, 28, 49-62. http://dx.doi.org/10.1023/B:NEFO.0000031331.08847.49

[31] Hua, L.R., Guo, G.P., Micheal, B., Stefania, G. and Salvatore, C. (2006) Evaluation of Chlorophyll Content and Fluorescence Parameters as Indicators of Drought Tolerance in Barley. Agricultural Sciences in China, 5, 751-757. http://dx.doi.org/10.1016/S1671-2927(06)60120-X

[32] Longenberger, P.S., Smith, C.W., Duke, S.E. and McMichael, B.L. (2009) Evaluation of Chlorophyll Fluorescence as a Tool for the Identification of Drought Tolerance in Upland Cotton. Euphytica, 166, 25-33. http://dx.doi.org/10.1007/s10681-008-9820-4

[33] Brestic, M. and Zivcak, M. (2013) Molecular Stress Physiology of Plants. Springer India Inc., New Delhi.

[34] Ehlert, B. and Hincha, D.K. (2008) Chlorophyll Fluorescence Imaging Accurately Quantifies Freezing Damage and Cold Acclimation Responses in Arabidopsis Leaves. Plant Methods, 4, 1-7. http://dx.doi.org/10.1186/1746-4811-4-12

[35] Rizza, F., Pagani, D., Stanca, A. and Cattivelli, L. (2001) Use of Chlorophyll Fluorescence to Evaluate the Cold Acclimation and Freezing Tolerance of Winter and Spring Oats. Plant Breeding, 120, 389-396. http://dx.doi.org/10.1046/j.1439-0523.2001.00635.x

[36] FAO (2009) Global Agriculture towards 2050. Briefing Paper for FAO High-Level Expert Forum on "How to Feed the World 2050", Rome, 21-23.

[37] Strable, J. and Scanlon., M.J. (2009) Maize (Zea mays): A Model Organism for Basic and Applied Research in Plant Biology. Cold Spring Harbor Protocols, 2009, Article ID: pdb.emo132. http://dx.doi.org/10.1101/pdb.emo132

[38] Ku, L.X., Zhao, W.M., Zhang, J., Wu, L.C., Wang, C.L.,Wang, P.A., Zhang, W.Q. and Chen,Y.H. (2010) Quantitative Trait Loci Mapping of Leaf Angle and Leaf Orientation Value in Maize (Zea mays L.). Theoretical and Applied Genetics, 121, 951-959. http://dx.doi.org/10.1007/s00122-010-1364-z

[39] Li, Q., Yang, X.H., Xu, S.T., Cai, Y., Zhang, D.L., Han, Y.J., Li, L., Zhang, Z.X., Gao, S.B., Li, J.S. and Yan, J.B. (2012) Genome-Wide Association Studies Identified Three Independent Polymorphisms Associated with $\alpha$-Tocopherol Content in Maize Kernels. PLoS ONE, 7, e36807. http://dx.doi.org/10.1371/journal.pone.0036807

[40] Arnon, D.I. (1949) Copper Enzymes in Isolated Chloroplasts. Polyphenoloxidase in Beta Vulgaris. Plant Physiology, 24, 1-15. http://dx.doi.org/10.1104/pp.24.1.1

[41] Zhang, Z.S., Li, G., Ga, H.Y., Zhang, L.T., Yang, C., Liu, P. and Meng, Q.W. (2012) Characterization of Photosynthetic Performance during Senescence in Stay-Green and Quick-Leaf-Senescence Zea mays L. Inbred Lines. PLoS ONE, 7, e42936.

[42] Zhang, W.Y., Xu, Y.C., Li, W.L., Yang, L., Yue, X., Zhang, X.S. and Zhao, X.Y. (2014) Transcriptional Analyses of Natural Leaf Senescence in Maize. PLOS ONE, 9, e115617. http://dx.doi.org/10.1371/journal.pone.0115617 


\section{Appendices}

Table 1. Descriptive statistics of traits for Chl content in inbred lines population.

\begin{tabular}{ccccccccccccccccc}
\hline \multicolumn{1}{l}{ Trait SPAD-LSPAD-DChla-LChla-DChlb-LChla-DTChl-LTChl-DChla/b-LChla/b-D Chla\%-L } & Chla\%-D & Chlb\%-L & Chlb\%-D \\
\hline Max & 48.35 & 42.12 & 1.21 & 0.58 & 0.96 & 0.58 & 2.05 & 1.16 & 1.49 & 1.21 & 59.92 & 54.79 & 69.05 & 91.74 \\
Min & 26.33 & 18.32 & 0.18 & 0.04 & 0.26 & 0.06 & 0.55 & 0.12 & 0.44 & 0.09 & 30.95 & 8.26 & 40.08 & 45.21 \\
Range & 22.02 & 23.80 & 1.03 & 0.54 & 0.71 & 0.52 & 1.51 & 1.05 & 1.05 & 1.12 & 28.97 & 46.53 & 28.97 & 46.53 \\
Mean & 38.02 & 29.83 & 0.57 & 0.22 & 0.52 & 0.26 & 1.09 & 0.49 & 1.07 & 0.84 & 51.33 & 45.13 & 48.66 & 54.87 \\
SD & 4.34 & 4.81 & 0.18 & 0.10 & 0.13 & 0.10 & 0.30 & 0.19 & 0.19 & 0.17 & 4.85 & 5.85 & 4.85 & 5.85 \\
\hline
\end{tabular}

Note: SPAD value, Chlorophyll compounds content; Chla, Chlb: chlorophyll a and chlorophyll b content (mg/g); TChl: total chlorophyll (Chla + b) (mg/g); Chla/b: the ratio of chlorophyll a and b content; Chla\%, Chlb\%: chlorophyll a and b percent in total chlorophyll content; SD = standard deviation, SPAD reading and Chla/b have no unit.

Table 2. Correlation coefficients for SPAD readings and Chl concentration.

\begin{tabular}{|c|c|c|c|c|c|c|c|c|c|c|}
\hline Trait & SPAD-L & SPAD-D & Chla-L & Chlb-L & TChl-L & Chla/b-L & Chla-D & Chlb-D & TChl-D & Chla/b-D \\
\hline SPAD-L & 1 & & & & & & & & & \\
\hline SPAD-D & $0.561^{* *}$ & 1 & & & & & & & & \\
\hline Chla-L & 0.165 & 0.181 & 1 & & & & & & & \\
\hline Chlb-L & 0.280 & 0.257 & $0.845^{* *}$ & 1 & & & & & & \\
\hline TChl-L & 0.215 & 0.213 & $0.973^{* *}$ & $0.944^{* *}$ & 1 & & & & & \\
\hline Chla/b-L & -0.091 & -0.050 & $0.608^{* *}$ & 0.229 & 0.437 & 1 & & & & \\
\hline Chla-D & 0.068 & 0.186 & 0.245 & 0.295 & 0.265 & 0.068 & 1 & & & \\
\hline Chlb-D & 0.075 & 0.207 & 0.274 & 0.373 & 0.319 & -0.024 & $0.722^{* *}$ & 1 & & \\
\hline TChl-D & 0.051 & 0.177 & 0.267 & 0.339 & 0.297 & 0.029 & $0.951^{* *}$ & $0.949^{* *}$ & 1 & \\
\hline Chla/b-D & -0.144 & 0.016 & 0.153 & 0.014 & 0.088 & 0.350 & $0.533^{* *}$ & 0.258 & 0.436 & 1 \\
\hline
\end{tabular}

Note: SPAD: SPAD readings; Chla: Chlorophyll a; Chlb: Chlorophyll b; TChl: total chlorophyll (Chl a + b); Chla/b: the ratio of chlorophyll a and b; L: light; D: dark; ${ }^{* *}$ Significant at the 0.01 probability level. 


\section{Supplementary Information}

Table S1. Relative chlorophyll differences between selected inbreds under dark treatment.

\begin{tabular}{|c|c|c|c|}
\hline \multirow{2}{*}{ Inbred Lines } & \multicolumn{3}{|c|}{ Differential \% } \\
\hline & Chla & Chlb & Tchl \\
\hline chuan48-2 & 2 & 5 & 3 \\
\hline $4 \mathrm{~F} 1$ & -6 & 14 & 5 \\
\hline 303WX & 15 & -1 & 7 \\
\hline 9642 & -2 & 21 & 10 \\
\hline LY042 & -32 & 34 & 12 \\
\hline B77 & 35 & 14 & 24 \\
\hline 526018 & 30 & 22 & 26 \\
\hline TY2 & 33 & 18 & 26 \\
\hline 4019 & 34 & 19 & 27 \\
\hline 04K5686 & 33 & 22 & 28 \\
\hline $384-2$ & 31 & 31 & 31 \\
\hline 05W002 & 31 & 32 & 32 \\
\hline 238 & 39 & 26 & 33 \\
\hline M97 & 31 & 36 & 34 \\
\hline B113 & 36 & 32 & 34 \\
\hline EN25 & 46 & 22 & 35 \\
\hline D863F & 43 & 26 & 35 \\
\hline LY & 41 & 33 & 36 \\
\hline JY01 & 21 & 46 & 36 \\
\hline MN & 39 & 32 & 36 \\
\hline B73 & 49 & 21 & 36 \\
\hline B110 & 36 & 37 & 36 \\
\hline C8605 & 49 & 26 & 37 \\
\hline L3180 & 37 & 38 & 38 \\
\hline Zheng30 & 37 & 39 & 38 \\
\hline Dan360 & 36 & 40 & 38 \\
\hline A619 & 46 & 29 & 38 \\
\hline FCD0602 & 42 & 37 & 39 \\
\hline $835 a$ & 36 & 43 & 40 \\
\hline 3411 & 41 & 38 & 40 \\
\hline Si273 & 49 & 34 & 41 \\
\hline Chang3 & 43 & 40 & 42 \\
\hline Lx9801 & 42 & 42 & 42 \\
\hline $18-599$ & 46 & 38 & 42 \\
\hline K12 & 45 & 42 & 43 \\
\hline LG001 & 45 & 42 & 43 \\
\hline
\end{tabular}




\section{Continued}

\begin{tabular}{|c|c|c|c|}
\hline 04K5702 & 42 & 46 & 44 \\
\hline $835 b$ & 47 & 41 & 44 \\
\hline TY1 & 52 & 35 & 44 \\
\hline 501 & 47 & 42 & 45 \\
\hline C17 & 59 & 27 & 45 \\
\hline U8112 & 53 & 36 & 45 \\
\hline TY4 & 49 & 43 & 46 \\
\hline K14 & 30 & 54 & 47 \\
\hline Qi205 & 52 & 40 & 47 \\
\hline TY3 & 50 & 43 & 47 \\
\hline Zi330 & 53 & 40 & 47 \\
\hline 07KS4 & 59 & 54 & 56 \\
\hline Shen137 & 64 & 48 & 56 \\
\hline Shen5003 & 64 & 48 & 57 \\
\hline Zheng22 & 63 & 50 & 57 \\
\hline 268 & 61 & 54 & 57 \\
\hline TY9 & 63 & 52 & 58 \\
\hline 7884-4Ht & 66 & 50 & 59 \\
\hline Zheng28 & 66 & 49 & 59 \\
\hline Tian77 & 64 & 51 & 59 \\
\hline 05WN230 & 58 & 60 & 59 \\
\hline Ye8001 & 64 & 52 & 59 \\
\hline Liao159 & 65 & 51 & 59 \\
\hline 5213 & 64 & 54 & 59 \\
\hline TT16 & 65 & 55 & 59 \\
\hline HSBN & 68 & 49 & 59 \\
\hline JH96C & 65 & 53 & 60 \\
\hline IRF314 & 57 & 62 & 60 \\
\hline Ji63 & 64 & 57 & 60 \\
\hline HTH-17 & 66 & 56 & 61 \\
\hline Jiao51 & 65 & 55 & 61 \\
\hline $975-12$ & 72 & 52 & 62 \\
\hline Si434 & 70 & 52 & 62 \\
\hline Tie7922 & 70 & 54 & 63 \\
\hline Yan414 & 70 & 56 & 63 \\
\hline Q1261 & 71 & 56 & 63 \\
\hline Xun971 & 77 & 51 & 64 \\
\hline 1323 & 64 & 64 & 64 \\
\hline R15X1141 & 68 & 60 & 64 \\
\hline Dan4245 & 70 & 56 & 64 \\
\hline
\end{tabular}


N. C. Aye et al.

\section{Continued}

\begin{tabular}{|c|c|c|c|}
\hline TX5 & 67 & 62 & 64 \\
\hline K10 & 68 & 62 & 65 \\
\hline Dan3130 & 67 & 63 & 65 \\
\hline Ye52106 & 73 & 56 & 65 \\
\hline Yu87-1 & 70 & 60 & 65 \\
\hline 7327 & 72 & 58 & 65 \\
\hline Dan340 & 81 & 45 & 65 \\
\hline Ye515 & 70 & 62 & 67 \\
\hline Mo17 & 71 & 61 & 67 \\
\hline 8902 & 69 & 64 & 67 \\
\hline Liao138 & 74 & 60 & 67 \\
\hline Chang7-2 & 75 & 57 & 67 \\
\hline Ye478 & 73 & 63 & 68 \\
\hline W138 & 69 & 67 & 68 \\
\hline Lv28 & 71 & 65 & 68 \\
\hline J4112 & 76 & 61 & 69 \\
\hline ZB648 & 72 & 65 & 69 \\
\hline 1462 & 51 & 46 & 48 \\
\hline WH413 & 44 & 53 & 49 \\
\hline 812 & 51 & 49 & 50 \\
\hline Yu374 & 57 & 43 & 51 \\
\hline LXN & 60 & 42 & 51 \\
\hline M153 & 56 & 47 & 52 \\
\hline 5311 & 59 & 45 & 52 \\
\hline Dan599 & 58 & 47 & 52 \\
\hline M165 & 55 & 50 & 53 \\
\hline B111 & 61 & 46 & 53 \\
\hline HB & 61 & 44 & 53 \\
\hline TY10 & 60 & 47 & 53 \\
\hline Zhi41 & 62 & 46 & 54 \\
\hline B151 & 60 & 47 & 54 \\
\hline HYS & 59 & 50 & 54 \\
\hline Ji53 & 62 & 43 & 54 \\
\hline S22 & 61 & 46 & 55 \\
\hline P178 & 61 & 50 & 55 \\
\hline Zheng58 & 94 & 4 & 56 \\
\hline K22 & 60 & 51 & 56 \\
\hline R15 & 73 & 71 & 72 \\
\hline P138 & 77 & 66 & 72 \\
\hline Liao5114 & 78 & 66 & 72 \\
\hline
\end{tabular}




\section{Continued}

\begin{tabular}{|c|c|c|c|}
\hline ES40 & 75 & 69 & 72 \\
\hline Dan9046 & 78 & 65 & 73 \\
\hline Ji846 & 77 & 69 & 73 \\
\hline Si444 & 75 & 70 & 73 \\
\hline Zheng32 & 77 & 69 & 74 \\
\hline $3 \mathrm{H}-2$ & 76 & 72 & 74 \\
\hline HuangC & 80 & 69 & 74 \\
\hline Zong3 & 78 & 70 & 75 \\
\hline Qi319 & 77 & 73 & 75 \\
\hline NMJT & 82 & 71 & 78 \\
\hline $\mathrm{ZaC546}$ & 82 & 74 & 78 \\
\hline R08 & 86 & 70 & 78 \\
\hline DH29 & 85 & 72 & 79 \\
\hline Zheng35 & 92 & 80 & 86 \\
\hline Zheng29 & 93 & 83 & 88 \\
\hline Dan598 & 92 & 88 & 90 \\
\hline JH59 & 48 & 46 & 47 \\
\hline Ji853 & 50 & 45 & 47 \\
\hline Si446 & 84 & 48 & 69 \\
\hline TY7 & 76 & 64 & 71 \\
\hline 7381 & 49 & 44 & 47 \\
\hline Dong46 & 75 & 63 & 69 \\
\hline Nan21-3 & 74 & 63 & 69 \\
\hline
\end{tabular}

Note: Chla: Chlorophyll a; Chlb: Chlorophyll b; Tchl: Total chlorophyll (Chl a + b). 